\title{
EKSISTENSI BANK THITHIL DALAM KEGIATAN PASAR TRADISIONAL (STUDI KASUS DI PASAR KOTA BATU)
}

\author{
Aldrin Ali Hamka \\ Tyas Danarti \\ Fakultas Ekonomi Universitas Brawijaya
}

\begin{abstract}
This study aims to reveal the aspects that support the existence of banks thithil on economic activity in the Batu Market. Using a phenomenological approach, this study's findings are 1) preferences of traders in maximizing profits as bank thithil, 2) continuous interaction among traders and embedded in social networks, 3) ease of access for traditional traders who already have a network, 4) operation time of bank thihtil more flexible than formal financial institutions, easier to be reached by traditional traders 5) credit risk management to maintain the business.
\end{abstract}

Keywords: preferences, social networks, access, flexible, credit risk management

\section{A. LATAR BELAKANG}

Lembaga keuangan memiliki peranan penting di dalam perekonomian. Salah satunya adalah menyalurkan dana dari pihak yang kelebihan kepada pihak yang membutuhkan dana. Dalam sudut pandang ekonomi makro, aliran dana yang diberikan kepada masyarakat berguna sebagai stimulus kegiatan ekonomi masyarakat. Berdasarkan pada legalitas yang diberikan pemerintah, lembaga keuangan dibagi menjadi dua golongan, yaitu lembaga keuangan formal (legal) dan lembaga keuangan informal. Lembaga keuangan formal adalah suatu lembaga yang mempunyai dasar hukum (legalitas) dan dikenai regulasi oleh pemerintah. Sebaliknya pada lembaga keuangan informal tidak ada undang-undang dari pemerintah yang mengaturnya.

Dalam perekonomian pasar tradisonal, tidak hanya lembaga formal saja yang eksis, tetapi eksistensi lembaga keuangan informal juga mewarnai kegiatan di dalam pasar. Fenomena tersebut digambarkan oleh Boeke dalam Nugroho (2001: 4) sebagai dual economy, dimana terdapat sektor kapitalis dan subsisten yang berjalan bersama. Sektor formal seperti perbankan dan koperasi adalah institusi yang berada dibawah regulasi pemerintah, sedangkan ciri khas dari lembaga keuangan informal memiliki fleksibilitas yang tinggi dan tidak terkontrol oleh pemerintah.

Sampai saat ini belum ada data-data dari pemerintah yang dapat menjelaskan tentang kemampuan dan partisipasi lembaga keuangan informal dalam pembangunan. Eksistensi dari lembaga informal ini menunjukkan bahwa terdapatnya fungsi dan peranan lembaga tersebut terhadap masyarakat tertentu. Sehingga karena memiliki peranan, sebagian masyarakat akan mempertahankan keberadaan lembaga tersebut.

Lembaga keuangan informal yang hingga saat ini masih populer terutama pada masyarakat Jawa adalah rentenir. Namun demikian keberadaan rentenir atau pelepas uang (money lender) di Indonesia sulit terdeteksi pihak luar (outsiders) karena cenderung bersifat tertutup. Kondisi tersebut dikarenakan dalam kehidupan masyarakat luas di Indonesia, pekerjaan sebagai rentenir dipandang sebagai pekerjaan yang negatif. Namun di sisi lain rentenir juga dibutuhkan masyarakat tertentu, dan karena itulah rentenir menjadi eksis. Selain itu tidak ada hukum peradilan yang melarang pekerjaan tersebut. Namun jika ditarik dari sudut pandang agama dan norma masyarakat, rentenir adalah pekerjaan yang tidak dapat dibenarkan. Damsar (2001: 87) menuliskan 
bahwa untuk menghindari hal-hal yang bersifat melecehkan status sosial, rentenir menggunakan modal budaya (cultural capital) untuk memoles kembali gelar rentenir yang disandangnya, dengan cara mengaku bahwa dia beragama tertentu, rajin mendermakan uang, atau memakai kerudung dalam aktivitas kesehariannya. Sehingga dengan cara demkian, risiko terkucil dari suatu komunitas masyarakat dapat tereduksi.

Memahami fenomena rentenir yang sebetulnya telah eksis di dalam kegiatan ekonomi masyarakat sejak berabad yang lalu, bisa dinyatakan merupakan fenomena ekonomi yang terus-menerus beregenerasi. Berbagai upaya untuk mereduksi atau melenyapkan praktek rentenir telah dilakukan berulang-kali, salah satunya adalah program pemberian kredit berbiaya ringan bagi sektor usaha rakyat yang disalurkan melalui perbankan. Namun pada kenyataannya upaya tersebut tidak mampu menghilangkan praktik lembaga keuangan alternatif (informal), yang lazimnya disebut sebagai bank thithil.

Eksistensi bank thithil dapat ditemukan pada aktivitas ekonomi pasar tradisional, yang pada penelitian ini mengenai keberadaan bank thithil di pasar tradisional Kota Batu. Bank thithil di pasar tradisional tersebut sebagian besar nasabahnya adalah pedagang kecil. Kategori pedagang di pasar tradisional umumnya adalah pedagang yang bergerak dalam sektor informal dan berskala usaha kecil mikro atau usaha mikro. Umumya usaha tersebut dikelola dan dimiliki oleh orang miskin atau mendekati miskin.

Secara rasional manusia akan memilih sumber daya yang efisien. Hal tersebut dinyatakan juga oleh Damsar (1994:2) bahwa dalam persoalan ekonomi, manusia mempunyai kecenderungan "mengeluarkan biaya serendah mungkin untuk mendapakan keuntungan yang sebesar-besarnya." Dalam konteks pinjam meminjam dana, secara rasional semestinya peminjam (debitur) lebih memilih pinjaman yang berbiaya rendah. Namun pada kenyataanya, para pedagang di pasar tradisional masih banyak yang menjadi nasabah bank thihil, meskipun terdapat lembaga keuangan formal yang memberikan pinjaman dengan biaya (bunga) yang lebih rendah. Terlebih di sekitar Pasar Batu terdapat 20 lembaga keuangan formal baik berbentuk bank, koperasi, dan pegadaian. Situasi tersebut menggambarkan bahwa di Pasar Batu terdapat dualisme finansial, antara rentenir sebagai lembaga keuangan informal dan lembaga keuangan formal antara lain koperasi, perbankan, dan pegadaian.

Hadirnya dua bentuk lembaga keuangan yaitu formal dan informal yang sama-sama beroperasi di wilayah Pasar Batu pada kenyataannya dapat dimanfaatkan oleh para pedagang di pasar tersebut. Terdapat golongan pedagang yang tidak bisa mengakses dana pada lembaga keuangan formal sehingga menggunakan jasa bank thithil. Tetapi terdapat juga pedagang yang dapat memperoleh pendanaan dari lembaga formal dan sekaligus juga meminjam dana dari bank thithil. Oleh karenanya penelitian ini bertujuan untuk mengungkap hal-hal yang menunjang eksistensi bank thithil dalam aktivitas perekonomian pada Pasar Batu.

\section{B. KAJIAN TEORITIS}

\section{Teori Kelembagaan Yang Melingkupi Budaya Pasar dan Operasional Lembaga Keuangan Informal}

Yustika (2006:37) memaparkan bahwa, sampai saat ini terdapat berbagai variasi tentang defenisi kelembagaan (institutions). Definisi yang bermacam-macam makna tersebut diperbolehkan, sejauh konsep definisi dari kelembagaan tidak saling menegasi satu sama lain. Pengertian yang mencakup seluruh isi definisi kelembagaan adalah yang dikemukakan oleh Yustika (2006:42; Yaeger, 1999:9) , yaitu mendefinisikan kelembagaan sebagai aturan main (rules of the game) dalam masyarakat. Adapun karakteristik kelembagaan yang dipaparkan oleh Yustika (2006:43; North, 1990), bahwa di dalam kelembagaan terdapat larangan-larangan (prohibitions) dan persyaratan-persyaratan (conditional permission). 


\section{Journal of Indonesian Applied Economics}

Ilmu kelembagaan bersifat pragmatis, dimana kajian ilmu kelembagaan harus sesuai realita yang dibangun pada kondisi masyarakat. Pada kenyataannya kondisi dan permasalahan yang terjadi bersifat majemuk, sehingga terdapat kajian multidisiplin di dalam teori kelembagaan. Karena itu, teori kelembagaan melihat dulu fenomena yang terjadi, baru setelah itu dikaji. Dengan kata lain, seperti apa yang dipaparkan oleh Yustika (2006:46), bahwa ekonomi kelembagaan berkecenderungan untuk memilih pendekatan induktif.

Pasar tradisional memiliki suatu kelembagaan tersendiri. apabila dikaitkan dengan komposisi pedagang pasar, maka etnis Jawa mendominasi wilayah Pasar Kota Batu. Sehingga mau atau tidak mau, terdapat unsur budaya yang terbawa oleh masyarakat yang kemudian di aplikasikan di dalam pasar. Selain itu, interaksi dari sejumlah orang juga akan membentuk kelembagaan tersendiri sebagai garis haluan yang harus dipatuhi, baik itu formal mapun informal. Unsur kelembagaan dari lembaga keuangan informal juga mempengaruhi pola-pola interaksi antar pedagang dengan pihak lembaga keuangan informal. Dimana kelembagaan itu sendiri akan memberikan "aturan-aturan permainan" kepada pedagang untuk mengakses jasa dari bank thithil. Sehingga pola interaksi tersebut akan tergantung dari kelembagaan yang diterapkan.

\section{Implementasi Teori Modal Sosial dan Teori Jaringan Dalam Pasar}

Terdapat banyak definisi modal sosial yang mengaburkan konsep tersebut. Menurut National Statistic (2001:6), antara lain: energi sosial (social energy), jiwa komunitas (community spirit), kewajiban-kewajiban sosial (social bonds), (civic virtue), jejaring komunitas (community networks), "selubung" sosial (social ozone), persahabatan jangka panjang (extended friendship) , kehidupan komunitas (community life), sumber sosial (social resources), jejaring informal dan formal (informal and formal networks), (good neighbourliness), perekat sosial (social

glue). Dan konsep-konsep tersebut masih terus dikembangkan sesuai dengan kebutuhan pragmatisnya.

Sebelum teori modal sosial dikenal luas seperti pada saat ini Bordieu dan Wackman (1992:139) dalam Field (2005) menjelaskan tentang modal sosial yaitu sebagai berikut:

Modal Sosial adalah jumlah sumber-sumber daya, aktual atau virtual (tersirat) yang berkembang pada seorang individu atau sekelompok individu karena kemampuan untuk memiliki suatu jaringan yang dapat bertahan lama dalam hubungan-hubungan yang lebih kurang telah diinstitusikan berdasarkan pengetahuan dan pengenalan timbal balik.

Dengan pengertian tersebut, maka diperlukanlah biaya untuk memelihara jaringan agar mempunyai kelanggengan didalam relasi antar individu di dalam jaringan tersebut. Meskipun belum ada kesepakatan dari para ahli mengenai definisi dari pengertian modal sosial, para ahli menjelaskan dengan konsepnya masing-masing. Subejo (2004:3) merangkum definisi dari para ahli, yaitu seperti pada tabel berikut:

Dari tabel 1dapat dilihat, makna modal sosial (social capital) mempunyai esensi yaitu keterkaitan dan timbal-balik (reciprocity) antar manusia di dalam hubungan tidak hanya bersifat sosial tetapi juga menyangkut psikologi, budaya, dan kelembagaan yang didasari dengan kepercayaan (trust) untuk mencapai tujuan tertentu. Ditarik dari kompleksitas kajian, maka kajian modal sosial (social capital) bersifat multidisipliner. Dimana untuk memahami fenomena dari modal sosial yang tumbuh pada masyarakat diperlukan kajian ilmu sosial yang lain.

Salah satu efek lain dari modal sosial adalah apabila dihadapkan dengan individu, grup, atau kelompok yang mempunyai bentuk modal sosial yang tertutup dengan entitas (entity) yang lain. Dalam kondisi tersebut, alokasi sumberdaya akan terjadi hanya di dalam kelompok masing-masing. Maka diperlukannya sesuatu hal yang menjembatani (bridging) berbagai kelompok tersebut. 
Tabel 2.1: Pengertian dan Elemen Dasar dari Social Capital

\begin{tabular}{ll}
\hline Sumber & Pengertian danElemen Dasar dari Social Capital \\
\hline Coleman (1988) & $\begin{array}{l}\text { Social capital consists of some aspects of social structures, and they } \\
\text { facilitate certain actions of actors wheter persons or corporate actors } \\
\text { within the structure }\end{array}$ \\
\hline Putnametal (1993) & $\begin{array}{l}\text { Features of social organization, such as trust, norms (or reciprocity), } \\
\text { and networks (of civil engagement), that can improve the efficiency } \\
\text { of society by facilitating coordinated action }\end{array}$ \\
\hline Narayan (1997) & $\begin{array}{l}\text { The rules, the norms, obligations, reciprocitiy and trust embedded in } \\
\text { social relations, social structure and society's institutional } \\
\text { arrangement which enable members to achieve their individual and } \\
\text { community objectives }\end{array}$ \\
\hline Worl Bank(1998) & $\begin{array}{l}\text { Social capital refers to the insitutions, relationships, and norms that } \\
\text { shape the qualityand quantity of society's social interactions }\end{array}$ \\
\hline Uphoff(1998) & $\begin{array}{l}\text { Social capital can be considered as an accumulation of various types } \\
\text { of an intangible social, phsychological, cultural, institutional, and } \\
\text { relation assets that influence cooperative behaviour }\end{array}$ \\
\hline Dhesi (2000) & $\begin{array}{l}\text { Share knowledge, understandings, values, norms, and social } \\
\text { networks to ensure the intended results }\end{array}$ \\
\hline
\end{tabular}

Sumber: Jurnal Agro Ekonomi Vol. No 1 Juni 2004 (Hal 77-86)

Dari tabel di atas, makna modal sosial (social capital) mempunyai esensi yaitu keterkaitan dan timbal-balik (reciprocity) antar manusia di dalam hubungan tidak hanya bersifat sosial tetapi juga menyangkut psikologi, budaya, dan kelembagaan yang didasari dengan kepercayaan (trust) untuk mencapai tujuan tertentu. Ditarik dari kompleksitas kajian, maka kajian modal sosial (social capital) bersifat multidisipliner. Dimana untuk memahami fenomena dari modal sosial yang tumbuh pada masyarakat diperlukan kajian ilmu sosial yang lain.

Salah satu efek lain dari modal sosial adalah apabila dihadapkan dengan individu, grup, atau kelompok yang mempunyai bentuk modal sosial yang tertutup dengan entitas (entity) yang lain. Dalam kondisi tersebut, alokasi sumberdaya akan terjadi hanya di dalam kelompok masing-masing. Maka diperlukannya sesuatu hal yang menjembatani (bridging) berbagai kelompok tersebut.

Franke (2007:11) menjelaskan bahwa konsep dari modal sosial cenderung diasosiasikan dengan partisipasi sosial masyarakat dan dengan jaringan-jaringan kerja-sama dan solidaritas. Durlauf dan Fafchams (2004:1) merangkum dari berbagai pendapat para ahli; "social capital matters in understanding individual and group differences and further that successfully public policy design needs to account for the effects of policy on social capital formation". Sehingga dalam hal ini, modal sosial yang terbentuk dari sistem jaringan antar individu memiliki suatu pengaruh pada masyarkat dalam kempok tersebut.

Sejalan dengan kajian teori modal sosial, ilmu yang bersumber dari teori jaringan menguatkan bahwa perilaku dari suatu kelompok masyarakat bukanlah hasil dari akumulasi perilaku manusia yang berada di dalamnya. Akan tetapi terdapat semacam payung yang menaungi dari seluruh individu yang ada "di bawahnya". Wellman (1983:162) dalam Ritzer dan Douglas (2004:382) menjelaskan bahwa:

Analisis jaringan lebih ingin mempelajari keteraturan individu atau kolektivitas berperilaku ketimbang keteraturan keyakinan tentang bagaimana mereka seharusnya berperilaku. Karena itu pakar analisis jaringan mencoba menghindarkan penjelasan normatif dari perilaku sosial. Mereka menolak setiap penjelasan nonstruktural yang memperlakukan proses sosial sama dengan penjumlahan ciri pribadi aktor individual dan norma yang tertanam. 


\section{Journal of Indonesian Applied Economics}

Masih didalam Ritzer dan Goodman (2004:383), Granoveter (1973:1983) menambahkan bahwa dalam jaringan terdapat "kekuatan ikatan". Dimana ikatan sosial yang kuat seperti hubungan antara soseorang dengan teman karibnya, sedangkan yang lemah adalah hubungan antara seseorang dengan kenalannya. Ikatan sosial yang kuat inilah yang akan muncul menjadi modal sosial.

Teori jaringan dan modal sosial mempunyai keterkaitan. Dalam hal ini, teori jaringan adalah dasar untuk membentuk relasi dan interaksi antar manusia. Sedangkan modal sosial adalah sesuatu yang terlekat (embedded) di dalam jaringan yang telah mapan. Sehingga apabila struktur jaringan sudah mapan dan kuat antar individu atau entitas, maka modal sosial akan muncul dalam jaringan tersebut. Konsep keterlekatan (embeddedness) juga ditekankan oleh Grannoveter di dalam Ritcher (2001:6) bahwa, "economic action take place within the networks of social relation that make up the social structured.", yang ditambahkan oleh Ritcher (2001:6; Di Maggio, 1990) bahwa "economic action is embedded not only in social structure but also in culture".

Dalam hal ini, jaringan antar pedagang pasar terbentuk di dalam interaksi. Di dalam interaksi itu dapat juga terjalin hubungan-hubungan dalam berbagai bentuk, salah satunya adalah hubungan yang berunsur ekonomi. Untuk mengembangkan jaringan ke dalam modal sosial diperlukanlah elemen yang dapat menjalin hubungan antar pedagang. Pada elemen modal sosial, di dalamnya terdapat unsur-unsur penting, yaitu : partisipasi dalam suatu jaringan, reciprocity, trust, norma sosial, nilai yang terkandung dalam masyarakat, dan tindakan proaktif. Dibutuhkan ke enam faktor tersebut untuk menumbuhkan modal sosial dalam interaksi sosial. Dalam masyarakat pasar tradisional, pedagang harus memiliki ke enam elemen tersebut, apabila menginginkan modal sosial. Modal sosial tersebut nantinya sebagai instrument untuk mengakses jasa dari lembaga keuangan informal, salah satunya adalah bank thithil.

\section{METODE PENELITIAN DAN ANALISIS DATA}

Ketertutupan aktivitas rentenir dengan nasabahnya terhadap pihak luar, dalam arti untuk didekati dan diwawancarai secara formal, merupakan fenomena yang unik dan sensitif jika dikaitkan dengan moral dan masalah agama. Untuk itu, penelitian dilakukan dengan cara metode partisipatif, dimana peneliti terjun menyatu bersama masyarakat sebagai partisipan. Sehingga dengan metode partisipatif, dapat mengeliminisasi hal-hal yang dapat memicu masalah sensitif dari masyarakat yang diteliti.

Pendekatan penelitan yang digunakan adalah dengan cara pemahaman terhadap fenomena yang terjadi. Pemahaman (verstehen1) terhadap fenomena dan perilaku manusia tidak sebatas tentang bagaimana masyarakat berperilaku, namun juga tentang makna yang tersembunyi di dalamnya. Pemahaman makna yang bertransformasi ke wujud perilaku ini dilakukan dengan cara pendekatan fenomenologis, dimana kajian tersebut menggunakan intuisi sebagai sarana untuk mencapai kebenaran (Sulistiani, 2008:55; Santoso, 2001:122).

Informan dipilih dengan cara purposive sampling, dimana informan dipilih sesuai dengan kriteria-kriteria yang layak untuk dijadikan sebagai informan.

1) Rentenir,

2) Pedagang pasar,

3) Pihak-pihak yang berada dalam lembaga keuangan formal,

4) Dinas Pasar Kota Batu,

5) Pemerintah Kota Batu.

6) Ketua paguyuban pasar

Adapun teknik pengumpulan data dilakukan dengan metode penelitian observasi partisipatif, dimana peneliti terjun secara langsung di dalam kegiatan di pasar tersebut. Di sela- 
sela kegiatan tersebut, peneliti akan mengobservasi, dan mewawancarai subjek penelitian secara informal.

Setelah data terkumpul, maka proses pengecekan dan validasi data untuk menunjang konsistensi data terhadap fenomena dilakukan dengan langkah-langkah sebagai berikut:

1) Triangulasi, dimana teknik ini digunakan untuk menyocokkan data dengan cara wawancara tak berstruktur dari berbagai sumber dalam waktu, tempat, dan orang yang berbeda.

2) Peer Examination, dengan cara meminta bantuan kolega melalui seminar dan diskusi untuk memberikan komentar.

3) Audit trail, pengenalan terhadap lokasi penelitian.

4) Multi-side design, mengumpulkan seluruh data, termasuk juga yang terlibat sebagai subjek penelitian, yaitu gender, usia, di berbagai tempat dan situasi. (Bungin, 2001:129130).

\section{Teknik Analisis Data}

Usman dan Akbar (2001:86) mengemukakan bahwa, secara garis besar analisis data adalah sebagai berikut:

1) Reduksi data, data-data yang terkumpul direduksi dan dicari yang mempunyai kesesuaian dengan fokus penelitian.

2) Display data, dimana penyajian data menggunakan bentuk matriks, network, chat, atau grafik.

3) Pengambilan keputusan dan verifikasi, yaitu mencoba mencari model, tema, hubungan, persamaan, hal-hal yang sering muncul dan sebagainya dalam bentuk suatu kesimpulan. Sedangkan proses verifikasi didapat dengan cara mengumpulkan data baru.

\section{PEMBAHASAN}

\section{Eksistensi Bank Thithil di Dalam Aktivitas 'Masyarakat' Pasar Batu}

Dualisme antara kehidupan lembaga keuangan formal dan eksistensi dari keberadaan rentenir merupakan hal yang nyata yang ditemui di aktivitas Pasar Batu. Situasi yang nampak adalah sikap perlindungan dari sebagian 'masyarakat' Pasar Batu kepada rentenir dengan cara "merahasiakan" keberadaannya merupakan wujud dari preferensi masyarakat yang masih menggunakan jasa rentenir. Sifat rahasia ini bukan berarti aktivitas rentenir dilakukan secara sembunyi-sembunyi, akan tetapi adalah sifat tertutupnya informasi mengenai segala sesuatu yang terkait dengan akses kepada aktivitas rentenir. Rentenir atau yang disebut sebagai 'bank thithil' yang hidup dalam aktivitas Pasar Batu memiliki sifat tertutup terhadap pihak yang berada di luar jaringan mereka.

\section{Ragam Bank Thithil; Preferensi Sebagai Usaha Utama atau Kegiatan off-trading}

Dalam observasi ditemukan fakta bahwa terdapat beragam jenis bank thithil yang beraktivitas di dalam pasar. Pada gambar 1 terlihat bagaimana komposisi dari jenis-jenis bank thithil yang beroperasi di pasar. Berdasarkan operasionalnya, lembaga keuangan informal di pasar terdapat dua jenis, yaitu arisan dan Bank Thithil. Sedangkan bank thithil terbagi menjadi dua berdasarkan posisi pemiliknya dalam 'masyarakat' Pasar Batu, yaitu : pertama, bank thithil dari intern pasar dimana aktor yang berperan adalah pedagang pasar sendiri, kedua, bank thithil yang berasal dari ekstern pasar yaitu "koperasi" dan mantan pedagang Pasar Kota Batu.

Di dalam penelusuran jejak rentenir, berhasil ditemukan karakteristik dari masingmasing "bank thithil" yang pelakunya dari internal pasar maupun dari eksternal. Pada umumnya, jenis rentenir yang berada di dalam pasar merupakan wujud dari optimalisasi sumber daya finansial para pedagang dalam mencari keuntungan. Dimana rentenir yang berasal dari intern, 


\section{Journal of Indonesian Applied Economics}

Vol. 4 No. 1 Mei 2010, 58-70

pekerjaan utamanya adalah berdagang sedangkan praktik 'bank thithil' yang dilakukan hanya sebagai kegiatan off-trading. Tidak ada klasifikasi pedagang kecil maupun besar untuk menjadi rentenir, meskipun pada umumnya adalah pedagang besar yang memiliki bedhak di dalam pasar. Pada dasarnya semua tingkat pedagang berdasarkan besar kecilnya modal yang dimiliki mempunyai kesempatan untuk menjalankan kegiatan off-trading sebagai rentenir. Kondisi tersebut didorong oleh intensnya interaksi antar pedagang yang kemudian secara alami membentuk jaringan, sehingga memudahkan terjadinya transaksi dana di antara mereka. Namun kemudahan untuk

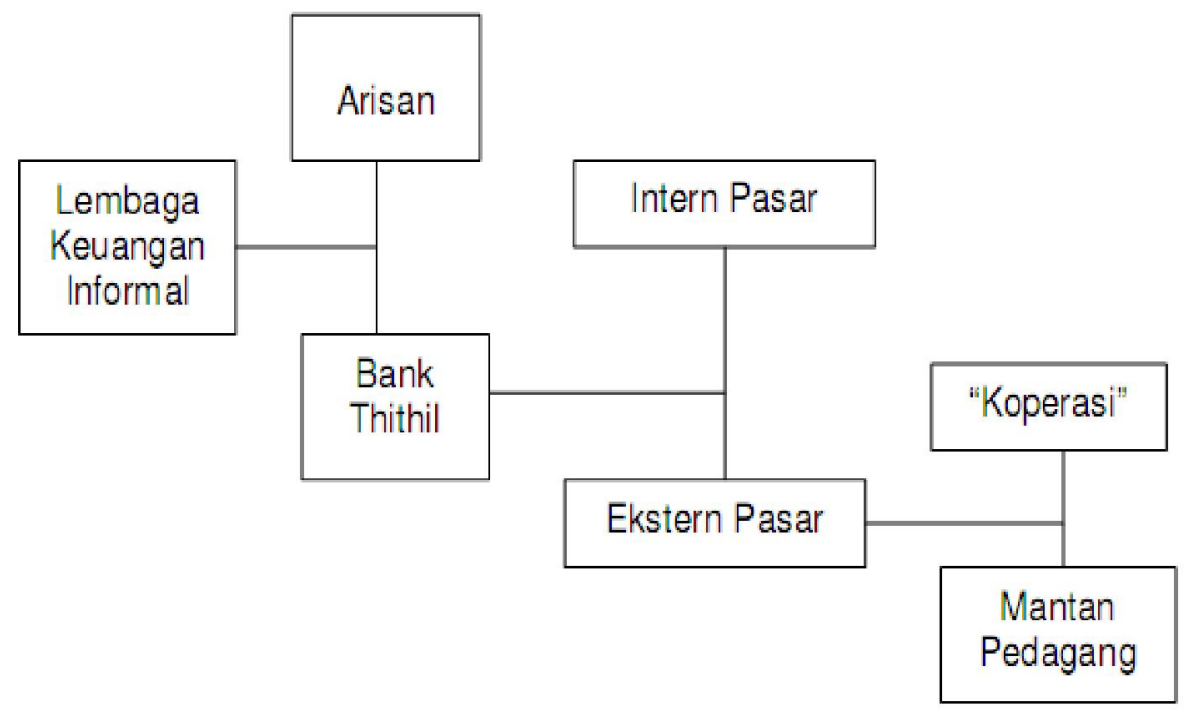

\section{Sumber: Hasil Survey (diolah) \\ Gambar 1. Jenis-Jenis Bank Thithil}

mengakses 'pasar dana' tersebut hanya berlaku kepada yang dianggap kalangan sendiri atau yang telah menjadi anggota jaringan.

Sedangkan bank thithil yang pelakunya berasal dari eksternal pasar, dibedakan menjadi dua; 1) rentenir yang dahulunya adalah pedagang Pasar Batu, dan 2) adalah rentenir yang murni berasal dari luar pasar. Berbeda dengan rentenir dari internal pasar yang memposisikan kegiatan 'bank thithil' sebagai kegiatan off-trading, maka rentenir dari eksternal justru kebalikannya yaitu sebagai usaha utama (core bussines). Dilihat dari poin intensitas berkomunikasi dengan nasabah potensial yaitu para pedagang, rentenir yang berasal dari eksternal pasar tentu sangat kurang jika dibanding rentenir internal. Namun hal tersebut bukan berarti kalangan rentenir eksternal tidak mempunyai jaringan dalam masyarakat pasar. Seiring dengan berjalannya waktu dan semakin bertambahnya jumlah transaksi serta individu yang terlibat di dalamnya pada akhirnya juga akan membentuk suatu jaringan sebagai modal untuk melebarkan kegiatan 'bank thithil' dari pelaku eksternal. Lebih jauh lagi, bank thithil seperti layaknya 'badan usaha' yang mapan juga mempunyai 'pegawai' untuk melakukan operasional usahanya. Fakta tersebut diperoleh dari keterangan Purwanto mengenai keberadaan rentenir yang beraktivitas di pasar yang bernama Pak Boi.

"Seperti Pak Boi itu anak buahnya sekitar 5 orang, ...".

Semakin jelas bahwa rentenir eksternal melakukan kegiatan bank thithil sebagai usaha utama, dimana operasionalnya ditunjang oleh 'pegawai' serta struktur tugas yang jelas. Sebagai sebuah 'lembaga' yang berorientasi profit, pelibatan orang lain yang dibayar ke dalam operasional rentenir bertujuan untuk mengekspansi pasar melalui layanan yang menjangkau. Dari upaya yang dilakukan tersebut, dapat diartikan bahwa pelaku eksternal berencana untuk melanggengkan dan bahkan memperkuat 'lembaga' yang disebut sebagai 'bank thithil' sehingga memposisikan kegiatan tersebut sebagai usaha utama. 
Rentenir jenis lain lagi adalah pelaku bank thithil yang mengaku sebagai pegawai koperasi. Namun apakah benar terdapat koperasi yang beroperasi sebagai bank thithil, atau ulah oknumoknum pegawai koperasi atau bahkan bukan keduanya. Pernyataan dari akuntan Bank Krisman Mandala yang bernama Pak Santo mengenai hal tersebut adalah sebagai berikut:

"Istilahnya kalo koperasi harian itu yang penting ada benderanya. Bendera itu kan namanya apa... KSP apa......Lha itukan istilahnya, dia pakai nama koperasi besar biar nggak di cap rentenir... itu gini lho mas, misalkan saya ya, misal punya uang ada koperasi di daerah Pare ya, saya pas kebetulan pinjam disini saya kan pinjam bendera dia... bukan koperasinya sendiri...jadi bukan orang koperasi sendiri. Jadi misalkan saya pas punya uang, 'saya pinjam benderanya'. Jadi artinya apa, jadi rentenir dengan kedok koperasi, kan begitu. Ya pakai koperasi, ya bukunya pakai thoknya (cap) koperasi, periksa aja mas nanti mau..."

Dari informasi diatas terdapat fakta perihal 'pinjam bendera' yang dilakukan oleh rentenir dengan meminjam nama dari sutu koperasi tempat dia menyimpan dananya, untuk kemudian digunakan sebagai kedok beroperasinya bank thithil. Hal tersebut membuktikan dua hal; bahwa 1) rentenir menggunakan simbol-simbol tertentu untuk menghilangkan anggapan buruk masyarakat terhadap jenis lapangan kerja yang dipakai olehnya, dan 2) memperhalus diksi yang digunakan untuk menawarkan produknya kepada masyarakat.

\section{Jejaring Sebagai Instrumen untuk Mendapatkan (dan Mempertahankan) Nasabah}

Hal pokok yang membedakan rentenir internal pasar dari rentenir eksternal adalah rentenir internal berinteraksi secara intens dengan para nasabah dan pedagang disekitarnya. Rentenir yang sehari-harinya juga berprofesi sebagai pedagang di dalam pasar akan mudah berinteraksi dengan yang lain. Interaksi tersebut bisa dilakukan dengan mudah karena rentenir internal juga mempunyai 'profesi utama' sebagai pedagang yang berbaur dalam aktivitas pasar, sehingga bisa leluasa berinteraksi dengan sesama pedagang meskipun bukan nasabahnya. Posisi pedagang yang bukan nasabah hakikatnya adalah sebagai nasabah potensial bagi rentenir internal karena hubungan di antara mereka terjalin sehari-harinya.

Berbeda dengan rentenir eksternal (berada di luar pasar), para rentenir tersebut jarang terlihat berbaur dengan pedagang setempat. Mereka hanya menarik "harian" kepada pedagang yang menjadi nasabahnya kemudian pergi tanpa berbincang-bincang dengan pedagang yang lain. Keterbatasan interaksi tersebut menimbulkan pertanyaan bagaimana cara rentenir memperluas jaringan yang ada di pasar. Padahal untuk mendapatkan nasabah, membuat jaringan antar pedagang yang ada di dalam pasar merupakan faktor yang penting. Seperti yang telah dijelaskan di awal mengenai ketertutupan informasi yang terkait dengan akses kepada aktivitas 'bank thithil', pedagang yang menginginkan jasa 'bank thithil' harus memahami aturan main (baca:kelembagaan) yang ada. Seperti yang dijelaskan oleh Pak Ngateman penjual pepaya yang berada lokasi pasar yang menaruh barang dagangannya di trotoar Jalan Dewi Sartika, sebagai berikut :

"Woo...ngono iku meloko konco-konco.. yo konco dodolan iku, nek gak melok konco ora iso, ngono iku mosok gelem srawung tah...". (Wooo... yang seperti itu, itu kamu harus ikut teman-teman... ya teman berjaualan itu, kalau tidak ikut tidak bisa, begitu itu apa mau bersosialisasi...).

Dengan demikian jelas bahwa 'aturan main' yang berlaku bagi para pedagang untuk mengakses "kreditan pasar" disyaratkan untuk memiliki suatu jaringan tertentu terhadap pedagang lain yang mempunyai akses langsung kepada rentenir. Hal ini sejalan dengan yang dikemukakan Yustika (2006:43; North, 1990), dimana untuk memasuki kelembagaan tersebut harus memiliki jaringan tertentu untuk menembus eksklusivisme dari sifat rentenir, karena di dalam kelembagaan itu sendiri terdapat larangan-larangan (prohibitions) dan persyaratanpersyaratan (conditional permission). 
Dari gambar 2 bagian I, nampak jelas terdapat lingkaran luar dan lingkaran dalam menurut sudut pandang "A" yang digambarkan sebagai sosok rentenir. " $A$ " telah memiliki nasabah yaitu, B,C,D, dan E yang tergolong lingkaran dalam, dimana anggota di lingkaran dalam mempunyai jaringan dan akses langsung kepada "A". Mereka berada di lingkaran dalam telah berulangkali bertransaksi dan melakukan kesepakatan, hal tersebut terlihat pada bagaimana rentenir setiap hari menarik nasabahnya.

Sedangkan lingkaran yang di luar pada gambar I menggambarkan pedagang F, G, H, I, J, K, $\mathrm{L}$, dan $\mathrm{M}$ yang tidak dapat mengakses rentenir secara langsung. Maka untuk mendapatkan akses tersebut, para pedagang yang ada di lingkaran luar harus meminta tolong untuk mengenalkan kepada A untuk mendapatkan kredit. Dengan demikian B,C,D, dan E merupakan penghubung (linkers) F, G , H, I, J, K, L, dan M kepada A. Mekanisme tersebut merupakan cara rentenir mendapatkan nasabah, dimana secara tidak langsung para nasabah juga berperan dalam memperluas jaringan rentenir.

Apabila telah kenal dengan A, maka seluruh pedagang yang tadinya berada di lingkaran luar akan masuk ke lingkaran dalam. Dimana di lingkaran dalam tidak memerlukan lagi penghubung untuk berinterkasi dengan rentenir. Sehingga komunikasi interpersonal dapat terjadi antara nasabah dengan rentenir, hal ini dapat dilukiskan dengan gambar II.

\section{Akses yang Lebih Terjangkau}

Salah satu kelebihan rentenir adalah jam operasional mereka. Kegiatan operasional tersebut tidak diatur kapan, selama pemilik dana berkehendak, maka operasi tersebut dapat berjalan. Selama observasi, di dapat bahwa rentenir bukan hanya pihak dari luar, akan tetapi praktek rentenir juga dilakukan oleh antar pedagang intern pasar.

Rentenir yang berada di dalam pasar menggunakan sumber daya dan jaringan mereka untuk mengoptimalisasikan keuntungan. Begitu pula jumlah rentenir tidak dapat terdeteksi dengan pasti, akan tetapi biasanya rentenir tersebut dapat terlihat aktivitasnya ketika jam 05.30 hingga 08.00 WIB.dimana pada waktu-waktu tersebut para pedagang "telah" memiliki
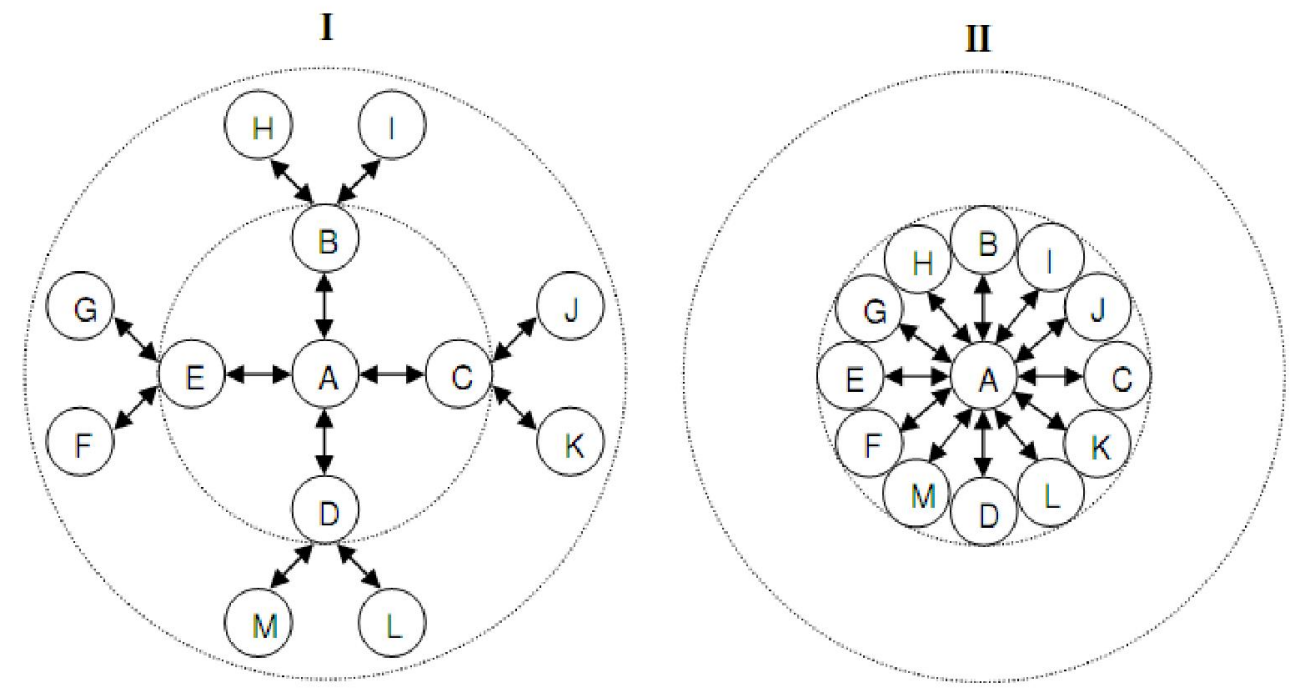

Sumber : Hasil Survey (diolah)

Gambar 2. Pola Jaringan Nasabah Yang Dimiliki Bank Thithil 
penghasilan. Sehingga kegiatan apapun yang menyangkut penagihan dana, umumnya dimulai pada jam-jam tersebut. Pelayanan jenis kredit yang paling umum adalah rolasan dimana apabila meminjam "10" maka harus dikembalikan sebanyak "12", dengan kata lain seumpama meminjam Rp. 100.000,, maka harus kembali sebesar Rp. 120.000,- dicicil dalam sepuluh hari.

Nampak dari lembaga keuangan informal, yaitu bank thithil, memiliki fleksibilitas yang tinggi dan lebih dapat menjangkau pedagang tradisional di Pasar Kota Batu. Salah satu fleksibilitas tersebut adalah tercermin dari pada jam berapa mereka beraktivitas dan memiliki kesesuaian waktu dengan pedagang tradisional. Selain itu, terdapat jejaring yang telah terbangun antar pedagang.

\section{Intuisi; Sumber Utama Analisis Kredit}

Pada transaksi pinjam meminjam dana, pemilik dana akan selalu berhadapan dengan resiko gagal bayar (default risk). Resiko terjadi ketika debitur tidak membayarkan bunga (imbal jasa) atau bahkan tidak mengembalikan pokok pinjaman sebagaimana yang tertera di kontrak. Upaya untuk meminimalkan default risk dimulai dari tahap analisis kredit. Dalam praktik perbankan pada umumnya calon debitur dianalisis dalam hal character, capacity, capital, collateral, condition (5 C's) untuk menentukan apakah calon debitur tersebut layak mendapatkan kredit. Sedangkan dari pendekatan manajemen resiko, dalam dunia perbankan dikenal metode kualitatif untuk mengukur resiko calon debitur. Dalam penerapan motode tersebut dibutuhkan semua informasi mengenai calon debitur (termasuk mengenai 5 C's) yang berupa data laporan keuangan dan semua informasi yang bisa diperoleh. Setelah itu, berdasarkan kumpulan informasi tersebut seorang bankir dengan menggunakan keahliannya akan memutuskan tingkat resiko dari calon debitur. Ketepatan analisis tersebut sangat tergantung dari pengalaman dan bersifat sangat subyektif. Tahap akhir dari metode qualitative ini, bisa disamakan dengan 'metode analisis' pelaku bank thithil dalam menentukan 'kelayakan' calon nasabahnya.

Pada praktik bank thithil, meskipun calon peminjam tidak mempunyai informasi laporan keuangan atau data tertulis yang menunjang pengambilan keputusan oleh rentenir mengenai disetujui atau tidak permintaan pinjaman, seorang rentenir tetap melakukan 'analisis kredit'. Analisis kredit dilakukan berdasarkan 'intuisi' untuk 'membaca' kesungguhan dan karakter dari peminjam. Keahlian menganalisis dengan memakai intuisi didapat berdasarkan pengalaman dan terasah dengan semakin seringnya berinteraksi dengan para peminjam. Seperti yang diceritakan oleh Pak As sebagai berikut :

"Ningali rupane tiyang thok, rupane tiyang nakal kalih mboten ngerti kulo, saestu cirine nang moto. Lha nggih, mulae sing sae nopo mboten nggih, dados njenengan ngutangaken dhuwik, sampean tangleti riyin. Sampean tingali saestu, maksude sing saestu, saestu-saestu tiyang niki ndlewer nopo mboten. Maksude delewer niku tiyang niki temen, temen-temen nyelang awak iki, mbujuki opo ora. (melihat wajah orang tersebut saja, wajahnya orang nakal dan tidak saya tahu, sungguh cirinya terletak pada mata. Lha iya, pada mulanya yang enak atau tidak ya, jadi [misalnya] Anda meminjami uang, anda beri pertanyaan terlebih dahulu. Anda lihat sungguh-sungguh, maksudnya sungguh-sunguh, sungguh-sungguh bahwa orang ini ndhelewer atau tidak. Maksudnya itu orang tersebut betul-betul pinjam kepada kita, berbohong atau tidak)".

Dari pengalaman Pak As, ciri dari seseorang yang bersungguh-sungguh untuk mendapatkan dana dapat dilihat dari mata calon nasabah tersebut. Sehingga dengan intuisi tersebut risiko dapat terminimalisir. Selain itu, Pak As juga melihat tanda-tanda lain terhadap calon nasabah.

"Kulo nek tiyang sing rupane ragu-ragu, ningali ngoten niku gak usah ngutangi dhuwik. Lha kulo kathah sing ilang riyin niku. Lha niku tiyang pinter! Oleh utangan emoh nyaur. Benten tiyang pinter rupanya ragu-ragu". (melihat yang demikian tidak usah diberi dana. Lha saya banyak kehilangan dahulu itu. Lha itu yang disebut dengan orang pinter! Dapat hutangan tidak mau membayar. Berbeda antara orang pinter dan orang ngerti iku, harus teliti dan waspada). 


\section{Journal of Indonesian Applied Economics}

Vol. 4 No. 1 Mei 2010, 58-70

Pengakuan informan pelaku bank thithil tersebut menjelaskan bahwa proses analisis kredit yang dilakukan ditekankan pada analisis karakter. Seperti halnya pada lembaga keuangan formal, faktor karakter nasabah menjadi faktor kunci untuk memutuskan kelayakan kredit, dalam arti meskipun dari faktor jaminan, kapasitas, dan modal seorang nasabah layak mendapatkan kredit, namun jika karakternya memungkinkan untuk melakukan moral hazard maka penilaian akhir danggap tidak layak mendapatkan kredit.

Sedangkan pada lembaga keuangan informal (bank thithil), salah satu alasan mengapa faktor karakter yang menjadi dasar pemberian kredit, karena pada umumnya nasabah tidak memiliki kemampuan dalam hal permodalan maupun jaminan. Sehingga penilain kelayakan kredit didasarkan pada karakter dan kapasitas. Kapasitas nasabah didasarkan pada profesi atau mata pencaharian sebagai pedagang, atau bisa dikatakan keberadaannya sebagai pedagang memungkinkan nasabah untuk mempunyai sumber pengembalian pinjamannya. Namun tetap kunci terakhir ada pada hasil penilaian pada karakter nasabah. Informasi mengenai karakter nasabah digali bukan dengan pertanyaan yang mendetil ataupun rekam jejak dari lembaga keuangan lain, namun dilakukan dengan mengandalkan intuisi dan tanda-tanda (gesture) dari nasabah.

\section{E. KESIMPULAN DAN REKOMENDASI}

Eksistensi dari keberadaan bank thithil ditunjang oleh berbagai hal; yaitu preferensi seseorang dalam memaksimalkan profit dari pendapatannya, adanya nasabah yang masih mau mengakses dana dari bank thithil, interaksi antar pedagang yang berlangsung secara terus-menerus dan melekat di dalam jejaring sosial, akses yang jauh lebih mudah bagi para pedagang tradisional yang telah memiliki jaringan. Selain itu, waktu beroperasinya bank thithil yang lebih fleksibel daripada lembaga keuangan formal, sehingga lebih mudah dijangkau oleh pedagang-pedagang tradisional di Pasar Kota batu yang beraktivitas mulai dini hari. Eksistensi ini pula harus didukung dengan manajemen risiko kredit yang dipunyai bank thithil itu sendiri dalam mempertahankan usahanya.

\section{DAFTAR PUSTAKA}

Akbar dan Usman.2001. Metodologi Penelitian Sosial. PT. Bumi Aksara: Jakarta.

Bungin, Burhan. 2001. Metodologi Penelitian Kualitatif: Aktualisasi Metodologis ke Arah Ragam Varian Kontemporer. Rajawali Pers: Jakarta.

Bungin, Burhan. 2006. Metode Penelitan Kualitatif. PT. Raja Grafindo Persada: Jakarta.

Damsar. 1997. Sosiologi Ekonomi. PT. Raja Grafindo Persada: Jakarta.

Damsar. 2006. Sosiologi Uang. Andalas University Press: Padang.

Durlauf, Steven. N dan Fafchams, Marcel. 2004. Social capital.

Field, John. 2005. Modal Sosial. Penerbit Bina Media Perintis: Medan.

Franke, Sandra, 2005. Measurement of Social Capital : Reference Document for Public Research, Development, and Evaluation.

Hasbullah, Jousairi.2006. Social Capital: Menuju Keunggulan Budaya Manusia Indonesia. MRUnited Press: Jakarta.

Hendaya dan Bustaman. 2007.Fenomena Lembaga Keuangan Mikro dalam PersprektifPembangunan 
Eksistensi Bank Thithil

Hamkas dan Danarti

ekonomi Pedesaan. http:// pse.litbang. deptan.go.id/ind/pdffiles/ Semnas4Des07_MP_A_Rachmat.pdf(diakses pada 19 Agustus 2009)

Jeromi, P.D. 2007. Regulation of Financial Institutions: A Study of Money Lenders in Kerala (dalam Reserve Bank of India Occasional Papers, vol. 28. No.1, Summer 2007).

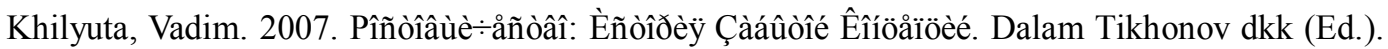
Áàiêàcñê $\hat{A}^{3} a ̊ n ̃{ }^{3} \hat{e}$. No. 16 (381), Èpíü 2007 ãîà (halaman 38-42). http://www.nbrb.by/bv/arch/ Stat/2007/381.pdf. (diakses pada 15 Mei 2009).

Kuncoro dan Suhardjono. 2002. Manajemen Perbankan : Teori dan Aplikasi. BPFE:Yogyakarta.

Midjan, Pardjoko. 2007. Pemberdayaan Pekerja Informal Perempuan di Pedesaan. http: //www. menkokesra.go.id/pdf/deputi6/ pekerja_perempuan_informal_nov2007.pdf. (Diakses pada tanggal 19 Agustus 2009)

Nissanke, Machiko dan Aryeetey, Ernest. Institutional Analysis Of Financial Market Fragmentation In Sub-Saharan Africa: A Risk-Cost Configuration Approach. http:/www.wider.unu.edu/ publications/working-papers/research-papers/2006/en_GB/rp2006-87/_files/ 78091787149576033/default/rp2006-87.pdf. (24 Mei 2009)

Nugroho, Heru. 2001. Uang, Rentenir, dan Hutang Piutang di Jawa. Pustaka Pelajar : Yogyakarta.

Nurmanaf, A. Rozany. 2007. Lembaga Informal Pembiayaan Mikro Lebih Dekat Dengan Petani. Dalam Analisis Kebijakan Pertanian.Volume 5 No. 2, Juni 2007:99-109. http:// pse.litbang.deptan.go.id/ind/pdffiles/ISU5-2a.pdf (diakses pada tanggal 19 Agustus 2009)

Policis/PFRC. 2006. Illegal Lending in the UK. http://www.berr.gov.uk/files/file35171.pdf. (diakses pada tanggal 16 Mei 2009).

Ridwan, Moh. 2006. Skripsi tak diterbitkan; Determinan Dari Kredit Rentenir Untuk Pedagang Mikro ( Studi Kasus pada Pedagang Mikro di Pasar Tradisional Gunung Kidul, Yogyakarta). Universitas Islam Yogyakarta.

Robinson, Jeffrey. An Economic Sociology of Entry Barriers: Business Entry and The Inner City Market. (diakses pada 31 Juli 2009)

Soesilo, Nining Astuti I. 2005. The Role of Micro financial and Micro Entrepreneur in Poverty Eridication Efforts in Indonesia. http://www.unescap.org/pdd/calendar/PovDecade/ RT\%20papers/Soesilo.pdf. (diakses pada tanggal 22 Mei 2009).

Sulistiani, E. Heni. 2008. Skripsi tak diterbitkan :Modal Sosial Pada Petani-Tengkulak Komoditas Kakao: analisis mikro dan meso relasional (Studi Kasus di Desa Donomulyo Kecamatan Donomulyo Kabupaten Malang) Tak Diterbitkan: Universitas Brawijaya Malang.

Wijaya, Faried. 1999.Perkreditan, Bank, Lembaga-lembaga Keuangan. BPFE:Yogyakarta

Yustika, Ahmad Erani. 2006. Ekonomi Kelembagaan: Definisi, Teori, dan Strategi. Bayumedia Publishing: Malang.

http://202.155.2.90/corporate_actions/new_info_jsx/jenis_informasi/01_laporan_keuangan/ 04_Annual\%20Report/2007/Bank\%20Ekonomi\%20Raharja\%20(BAEK)/ LAPORAN\%20TAHUNAN\%20PT\%20BANK\%20EKONOMI\%20RAHARJA\%20Tbk\%20TAHUN\%202007/ 12.\%20Sumber\%20Daya\%20Manusia.pdf 
Journal of Indonesian Applied Economics

Vol. 4 No. 1 Mei 2010, 58-70

http://els.bappenas.go.id (diakses pada tanggal 8 Februari 2009, pukul 13:03)

http://rbidocs.rbi.org.in/rdocs/Publications/PDFs/82931.pdf (diakses pada 16 Mei 2009).

http://www.bankmaspion.co.id/SDM.pdf

http://www.cr.gov.hk/en/publications/docs/18-e.pdf(diakses pada tanggal 20 April 2009, pukul 10:48)

http://www.financialregulator.ie (diakses pada tanggal 20 April 2009. pukul 10:57)

http://www.itsyourmoney.ie ( diakses pada tanggal 20 April 2009, pukul 10:49)

http://www.minlaw.gov (diakses pada tanggal 20 April 2009, pukul 10:57)

http://www.policyresearch.gc.ca/doclib/Measurement_E.pdf(diakses pada 13 Mei 2009).

http://www.ssc.wisc.edu/econ/archive/wp2004-12.pdf (diakses pada 13 Mei 2009).

http://www.surabayapost.co.id (diakses pada tanggal 25 April 2009, pukul 20:10)

http://www.uns.ac.id/data/0019.pdf (diakses pada 1 Mei 2009). 